\title{
VIBRATION CHARACTERISTICS ANALYSIS ON SHIP PROPULSION SYSTEM TAKING HULL DEFORMATIONS INTO ACCOUNT
}

\author{
Zhe Tian, Xinping Yan, Cong Zhang, Yeping Xiong, Ping Yang
}

Original scientific paper

Since an evident tendency of the shipbuilding is that the sizes of ships are larger and larger, the dynamic interactions between the propulsion system and ship hull in large scale ships are much severer than those of the small sized ships. Ship hull deformations caused by the action of heavy excited wave forces could affect the vibration characteristics of the propulsion system through bearings mounted on the ships. The reliability and safety of the propulsion system would be in a dangerous condition. In this paper, a novel simplified hull-propulsion system mathematical model is presented to investigate the dynamic interactions between the ship propulsion and hull deformations. Ship hull deformations were obtained as the excited forces under different sea conditions by numerical analysis. Then, based on the gained hull deformations, variable parameters involving stiffness of support bearings are considered on the vibration characteristics of propulsion. The findings of this work may provide a new insight to keep economy and security in both shipbuilding and ship operation fields.

Keywords: hull- propulsion system interactions; marine propulsion system; variable parameters; vibration behaviour

Analiza značajki vibracija na brodskom porivnom sustavu uzimajući u obzir deformacije trupa broda

Izvorni znanstveni članak

Budući da je u brodogradnji očita tendencija izgradnje sve većih brodova, dinamičke interakcije između porivnog sustava i trupa mnogo su oštrije kod velikih nego kod malih brodova. Deformacije brodskog trupa izazvane jakim silama valova mogle bi utjecati na značajke vibracija porivnog sustava preko ležajeva postavljenih na brodu. Pouzdanost i sigurnost porivnog sustava bila bi u opasnosti. U ovom se radu predstavlja matematički model novog pojednostavljenog porivnog sustava u svrhu istraživanja dinamičkih interakcija između brodskog porivnog sustava i deformacija trupa. Deformacije brodskog trupa dobivene su numeričkom analizom kao uzbudne sile pri različitim morskim uvjetima. Zatim su se, na temelju dobivenih deformacija trupa, razmotrili različiti parametri koji su uključivali krutost nosača ležaja u odnosu na karakteristike vibracija porivnog sustava. Rezultati ovoga rada mogu doprinijeti ekonomičnosti i sigurnosti u izgradnji i pogonu brodova.

Ključne riječi: brodski porivni sustav; interakcije trup-porivni sustav; ponašanje vibracija; varijabilni parametri

\section{Introduction}

Propulsion system plays an important role in the ship's operation which provides power transmission from the main engine to the propeller. With the fast development of large ships, problems of the interactions between propulsion system- hull deformations become more prominent. For the large scale ships, propulsion is always subjected to many extreme sea loadings due to the waves and dynamical impacts. The design of propulsion system follows the traditional empirical process without considering the hull-propulsion interactions [1]. Lots of statistical reports $[2,3]$ have been studied that the malfunctions of propulsion system claimed about 132 million dollars from 2005 to 2011. Therefore, the dynamic interactions between the ship hull and propulsion system should be concerned to guarantee the reliability and safety for the operations. However, most previous studies focus on the misalignment and vibration of propulsion with the effect of main engine and propeller, but rarely involve the effect of hull deformations whilst the vessels operate in rough sea conditions $[4 \div 10]$.

A study of the shaft line alignment with hull deformations was taken by Murawski [11]. Different loading conditions in the dead water were calculated in his word while the dynamic influence of waves on propulsion system should be considered during the ship's operations. By considering hull excitations, Xiong and Xing $[12,13]$ investigated vibration on a single degree-offreedom equipment on the ship involving hull, equipment and nonlinear isolator while propulsion system with bearings and propeller is a more complicated multi- degree-of-freedom system. Vibration of the ship stern with propulsion was simulated and experimented by Liu who mainly concentrated on the ship stern vibration [14]. Compared with other equipment mounted on the ship, the propulsion, especially for the large vessel, always has a long length which needs two or more bearings' support. As a result, the hull deformations on the location of each bearing should be fully considered. Based on the FEM (Finite Element Method) model, Yang [15] investigated the natural stern resonance of the propulsive shaft and the hull, respectively. Avoiding resonance between the hull and propulsion during the shipbuilding is an idealized way to keep the reliability of the unit. Its limitation is also obvious where more factors such as inertia, friction, misalignment and overheat could change the properties of the propulsion and hull. Meanwhile once frequencies of hull deformation from the wave excitation agree with the natural of propulsion, the resonance occurs as well.

This paper is concerned with the vibration of the propulsion system which has suffered from the hull deformations. As the interactions between the hull and propulsion system are the main sources of the transverse vibration of the propulsion, a novel 2 dimensional multidegree-of-freedom simplified propulsion system mathematical model is established and validated by the FEM calculation. Then, with the parameters of a kind of real container ship, series of numerical studies involve model validation and dynamic characteristics are carried out to assess the effect of propulsion caused by hull deformations. Based on the studies, the propulsion system mathematical model provides a fast way to calculate the vibration responses of propulsion system subjected to hull 
excitations. At the same time, it can be regarded as a reference to verify the accuracy of the FEM model calculations for the similar kind of large vessels during their design and reconstruction process.

\section{Mathematical model of propulsion system}

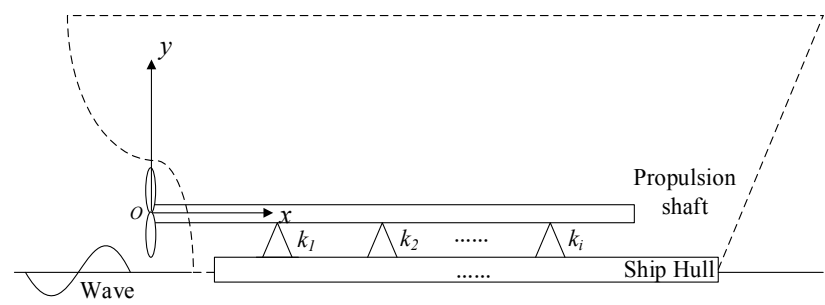

Figure 1 The overall of the integrated coupling hull-propulsion system

As a complicated structure, a ship has many components. Ignoring the unrelated equipment, a simplified model involves ship hull, propulsion shaft, propeller and bearings, assumed to assess the interaction between propulsion and ship hull in this paper, shown as Fig. 1. It can be seen that the propulsion system which consists of shaft and the propeller connects to the ship through the support bearings. Striking the ship hull heavily, the hydrodynamic loadings lead to the ship deformations. Accelerations from the hull deformations on the support bearings could easily make the vibration of the propulsion system intensive. If the violent vibration of the propulsion system lasts for a long time, misalignment and overheating of the propulsion will take place. Bending direction is mainly considered for the coupling interactions. The propulsion shaft is idealized as a uniform flexible cylindrical beam (neglecting flange disks) with length $L$, diameter $D$, mass density per unit length $\bar{m}$. The propulsion shaft is divided into $(i+1)$ segments by $i$ support bearings with lengths $L_{1}, L_{2}, \ldots, L_{i+1}$ respectively. The bending stiffness of the $i^{\text {th }}$ beam is $E I_{i}$ and the stiffness of the $i^{\text {th }}$ bearing is $k_{i}[16]$.

\subsection{Dynamic equations of propulsion system}

The propulsion system potential energy, the propulsion system kinetic energy, and the work done by hull deformations are constructed for further use. The displacements of the $n$th segments of propulsion shaft are defined as $w_{n}(x, t)$. The potential energy of the deformed whole propulsion shaft is written as

$$
E_{p}(t)=\frac{1}{2} \sum_{n=1}^{i+1} \int_{L_{n}^{-}}^{L_{n}^{+}} E I_{n}\left[\frac{\partial^{2} w_{n}(x, t)}{\partial x^{2}}\right]^{2} d x
$$

where $n=1,2, \ldots, i+1$.

The translation kinetic energy of the propulsion shaft is assumed to be the only contribution to the system kinetic energy, and one can write it as

$$
E_{k}(t)=\frac{1}{2} \sum_{n=1}^{i+1} \int_{L_{n}^{-}}^{L_{n}^{+}} \bar{m}\left[\frac{\partial w_{n}(x, t)}{\partial t}\right]^{2} d x
$$

where $n=1,2, \ldots, i+1$.
The work done by the applied deformed hull loading $F_{i}$ on the shaft through bearings is given by

$W_{f}(t)=\int_{0}^{L} F_{n} w(x, t) \Delta\left(x-x_{n}\right) d x$

where $x_{n}$ denotes the location of the $n^{\text {th }}$ bearing in the $o-x-y$ coordinate system, $\Delta()$ is a Dirac deltafunction.

To derive the dynamic equations of motion of propulsion system, we employ the Hamilton's principle. The propulsion system Lagrangian $L_{T}$ is constructed as follows.

$$
L_{T}(x, t, w)=E_{k}(t)-E_{p}(t)+W_{f}(t) .
$$

Based on the Hamilton principle or holonomic and conservative system, of all possible paths of motion to be taken between two instants of time $t_{1}$ and $t_{2}$, the actual path to be taken by the system corresponds to a stationary value of the integral $H_{s f}[17]$. That is

$\delta H_{s f}=\int_{t_{1}}^{t_{2}} \delta L_{T}(x, t, w) d t=0$

where $\delta$ is the variation operator.

Substituting Eq. $(1 \div 3)$ into Eq. (4) and making use of Eq. (5), the variations equations of the propulsion system can be derived as Eq. (6).

$$
\begin{aligned}
\delta H_{s f}= & \sum_{n=1}^{i+1} \int_{t_{1}}^{t_{2}} \int_{L_{n}^{-}}^{L_{n}^{+}} \bar{m} \frac{\partial w_{n}(x, t)}{\partial t} \delta \frac{\partial w_{n}(x, t)}{\partial t} d x d t \\
& -\sum_{n=1}^{i+1} \int_{t_{1}}^{t_{2}} \int_{L_{n}^{-}}^{L_{n}^{+}} E I_{n} \frac{\partial^{2} w_{n}(x, t)}{\partial x^{2}} \delta \frac{\partial^{2} w_{n}(x, t)}{\partial x^{2}} d x d t \\
& +\int_{t_{1}}^{t_{2}} \int_{L_{n}^{-}}^{L_{n}^{+}} F_{n} \Delta\left(x-x_{n}\right) \delta w(x, t) d x d t \\
= & \int_{t_{1}}^{t_{2}} \int_{L_{n}^{-}}^{L_{n}^{+}}\left(\sum_{n=1}^{i+1}\left(\bar{m} \frac{\partial^{2} w_{n}(x, t)}{\partial t^{2}}+E I_{n} \frac{\partial^{4} w_{n}(x, t)}{\partial x^{4}}\right)\right. \\
& \left.+\sum_{n=1}^{i} F_{n} \Delta\left(x-x_{n}\right)\right) \delta w(x, t) d x d t .
\end{aligned}
$$

As a result, the governing equations of the propulsion system are obtained by $\delta H_{s f}=0$ which is shown in Eq. (7).

$\sum_{n=1}^{i+1}\left(\bar{m} \frac{\partial^{2} w_{n}(x, t)}{\partial t^{2}}+E I_{n} \frac{\partial^{4} w_{n}(x, t)}{\partial x^{4}}\right)=-\sum_{n=1}^{i} F_{n} \Delta\left(x-x_{n}\right)$

Boundary conditions:

$\left.E I_{1} \frac{\partial^{3} w_{1}(x, t)}{\partial x^{3}}\right|_{x=0}=-\left.\tilde{\omega}^{2} m_{p} w_{1}(x, t)\right|_{x=0}$ 
$\left.E I_{1} \frac{\partial^{2} w_{1}(x, t)}{\partial x^{2}}\right|_{x=0}=-\left.\tilde{\omega}^{2} j_{p} \frac{\partial w_{1}(x, t)}{\partial x}\right|_{x=0}$

$\left.\frac{\partial^{2} w_{i+1}(x, t)}{\partial x^{2}}\right|_{x=L}=0$

$\left.\frac{\partial^{3} w_{i+1}(x, t)}{\partial x^{3}}\right|_{x=L}=0$.

Where $m_{p}$ is the mass of propeller, $j_{p}$ is the rotational inertia of propeller, $E I_{1}$ is the bending stiffness of the first segment at the left end of propulsion shaft.

Before proceeding further, the following notations are introduced for convenient description

$\alpha=\tilde{\omega}^{2} m_{p}, \beta=\tilde{\omega}^{2} j_{p}$.

\subsection{Solution of the governing equations}

Expanding Eq. (7), it can derive the whole dynamic equations of the propulsion shaft. For the $n^{\text {th }}$ segment of the propulsion shaft, one form of solution of the governing equation can be obtained easily by separation of variables using

$w_{n}(x, t)=\phi_{n}(x) q_{n}(t)$,

where $q_{n}(t)$ represents a time dependent generalized coordinate and $\phi_{n}(x)$ is the mode function of the $n$th segment of the propulsion shaft.

Substituting Eq. (13) into a governing equation of the $n$th segment propulsion shaft gives

$\frac{\phi_{n}^{(4)}(x)}{\phi_{n}(x)}+\frac{\bar{m}}{E I_{n}} \frac{\ddot{q}_{n}(t)}{q_{n}(t)}=0$,

where adopting the prime and dot nations to indicate partial derivatives with respect to $x$ and $t$, respectively [18].

Eq. (14) can yield two ordinary differential equations followed by

$$
\begin{aligned}
& \phi_{n}^{(4)}(x)-\xi_{n}{ }^{4} \phi_{n}(x)=0, \\
& \ddot{q}_{n}(t)+\omega^{2} q_{n}(t)=0 .
\end{aligned}
$$

in which

$$
\omega=\sqrt{\xi^{4} E I_{n} / \bar{m}}
$$

Eq. (15) can be solved in the usual way [18] to obtain the complete solution.

$$
\phi_{n}(x)=a_{n} \cos \xi_{n} x+b_{n} \sin \xi_{n} x+c_{n} \cosh \xi_{n} x+d_{n} \sinh \xi_{n} x,
$$

where $a_{n}, b_{n}, c_{n}$ and $d_{n}$ are real constants of the $n^{\text {th }}$ segment of shaft which must be evaluated so as to satisfy the boundary conditions at the end of the $n^{\text {th }}$ segment shaft.

The compatibility conditions establish relationships between the $n^{\text {th }}$ segment shaft and its adjacent segment shaft in aspect of displacement, slope, shear force and bending moment where displacement or slope are referred to as geometric boundary conditions, and shear force or bending moment are referred to as dynamic boundary conditions. The four shaft beam compatibility conditions of displacement, slope, shear force and bending moment on the $n^{\text {th }}$ bearing location $x_{n}$ are shown respectively as follows

$w_{n}\left(x_{n}^{l}, t\right)=w_{n+1}\left(x_{n}^{r}, t\right)$,

$\frac{\partial w_{n}\left(x_{n}^{l}, t\right)}{\partial x}=\frac{\partial w_{n+1}\left(x_{n}^{r}, t\right)}{\partial x}$

$E I_{n} \frac{\partial^{3} w_{n}\left(x_{n}^{l}, t\right)}{\partial x^{3}}=E I_{n+1} \frac{\partial^{3} w_{n+1}\left(x_{n}^{r}, t\right)}{\partial x^{3}}+k_{n} w_{n+1}\left(x_{n}^{r}, t\right)$,

$E I_{n} \frac{\partial^{2} w_{n}\left(x_{n}^{l}, t\right)}{\partial x^{2}}=E I_{n+1} \frac{\partial^{2} w_{n+1}\left(x_{n}^{r}, t\right)}{\partial x^{2}}$,

where $x_{i}^{l}$ and $x_{i}^{r}$ represent the left section and right section on the location $x_{i}$ of the shaft, respectively.

Substituting Eq. (18) into Eq. (13) and making use of the boundary conditions Eq. $(8 \div 11)$ and the compatibility conditions Eq. $(19 \div 22)$, it can derive the relationship of the real constants coefficients between the $n^{\text {th }}$ segment and $(n+1)^{\text {th }}$ segment in a matrix form as Eq. (23).

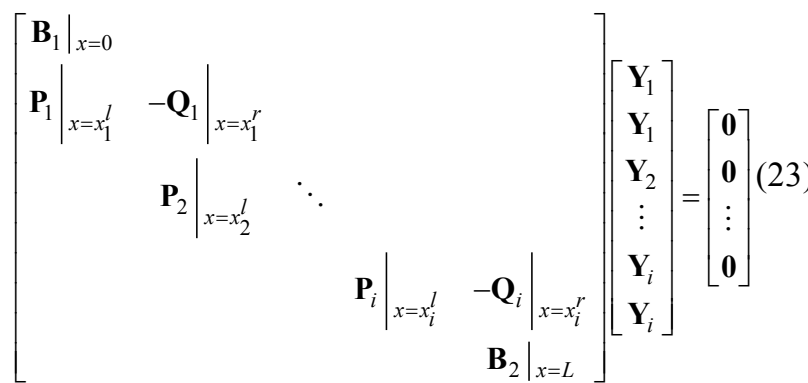

in which

$$
\begin{aligned}
& \mathbf{B}_{1}=\left[\begin{array}{llll}
E I_{1}\left(\cos \xi_{1} x\right)^{\prime \prime \prime}+\alpha \cos \xi_{1} x & E I_{1}\left(\sin \xi_{1} x\right)^{\prime \prime \prime}+\alpha \sin \xi_{1} x & E I_{1}\left(\cosh \xi_{1} x\right)^{\prime \prime \prime}+\alpha \cosh \xi_{1} x & E I_{1}\left(\sinh \xi_{1} x\right)^{\prime \prime \prime}+\alpha \sinh \xi_{1} x \\
E I_{1}\left(\cos \xi_{1} x\right)^{\prime \prime}+\beta \cos \xi_{1} x & E I_{1}\left(\sin \xi_{1} x\right)^{\prime \prime}+\beta \sin \xi_{1} x & E I_{1}\left(\cosh \xi_{1} x\right)^{\prime \prime}+\beta \cosh \xi_{1} x & E I_{1}\left(\sinh \xi_{1} x\right)^{\prime \prime}+\beta \sinh \xi_{1} x
\end{array}\right], \\
& \mathbf{B}_{2}=\left[\begin{array}{llll}
E I_{i+1}\left(\cos \xi_{i+1} x\right)^{\prime \prime \prime} & E I_{i+1}\left(\sin \xi_{i+1} x\right)^{\prime \prime \prime} & E I_{i+1}\left(\cosh \xi_{i+1} x\right)^{\prime \prime \prime} & E I_{i+1}\left(\sinh \xi_{i+1} x\right)^{\prime \prime \prime} \\
E I_{i+1}\left(\cos \xi_{i+1} x\right)^{\prime \prime} & E I_{i+1}\left(\sin \xi_{i+1} x\right)^{\prime \prime} & E I_{i+1}\left(\cosh \xi_{i+1} x\right)^{\prime \prime} & E I_{i+1}\left(\sinh \xi_{i+1} x\right)^{\prime \prime}
\end{array}\right],
\end{aligned}
$$


$\mathbf{P}_{n}=\left[\begin{array}{cccc}\cos \xi_{n} x & \sin \xi_{n} x & \cosh \xi_{n} x & \sinh \xi_{n} x \\ \left(\cos \xi_{n} x\right)^{\prime} & \left(\sin \xi_{n} x\right)^{\prime} & \left(\cosh \xi_{n} x\right)^{\prime} & \left(\sinh \xi_{n} x\right)^{\prime} \\ E I_{n}\left(\cos \xi_{n} x\right)^{\prime \prime \prime} & E I_{n}\left(\sin \xi_{n} x\right)^{\prime \prime \prime} & E I_{n}\left(\cosh \xi_{n} x\right)^{\prime \prime \prime} & E I_{n}\left(\sinh \xi_{n} x\right)^{\prime \prime \prime} \\ E I_{n}\left(\cos \xi_{n} x\right)^{\prime \prime} & E I_{n}\left(\sin \xi_{n} x\right)^{\prime \prime} & E I_{n}\left(\cosh \xi_{n} x\right)^{\prime \prime} & E I_{n}\left(\sinh \xi_{n} x\right)^{\prime \prime}\end{array}\right]$

$\mathbf{Q}_{n}=\left[\begin{array}{cccc}\cos \xi_{n+1} x & \sin \xi_{n+1} x & \cosh \xi_{n+1} x & \sinh \xi_{n+1} x \\ \left(\cos \xi_{n+1} x\right)^{\prime} & \left(\sin \xi_{n+1} x\right)^{\prime} & \left(\cosh \xi_{n+1} x\right)^{\prime} & \left(\sinh \xi_{n+1} x\right)^{\prime} \\ E I_{n+1}\left(\cos \xi_{n+1} x\right)^{\prime \prime \prime} & E I_{n+1}\left(\sin \xi_{n+1} x\right)^{\prime \prime \prime} & E I_{n+1}\left(\cosh \xi_{n+1} x\right)^{\prime \prime \prime} & E I_{n+1}\left(\sinh \xi_{n+1} x\right)^{\prime \prime \prime} \\ E I_{n+1}\left(\cos \xi_{n+1} x\right)^{\prime \prime} & E I_{n+1}\left(\sin \xi_{n+1} x\right)^{\prime \prime} & E I_{n+1}\left(\cosh \xi_{n+1} x\right)^{\prime \prime} & E I_{n+1}\left(\sinh \xi_{n+1} x\right)^{\prime \prime}\end{array}\right]$,

$\mathbf{Y}_{n}=\left[\begin{array}{llll}a_{n} & b_{n} & c_{n} & d_{n}\end{array}\right]^{T}, n=1,2, \ldots, i+1$.

Actually, the excited forces from hull deformations in Eq. (7) are applied on the propulsion shaft through the support bearings. With the forces consideration, Eq. (23) can be rewritten as

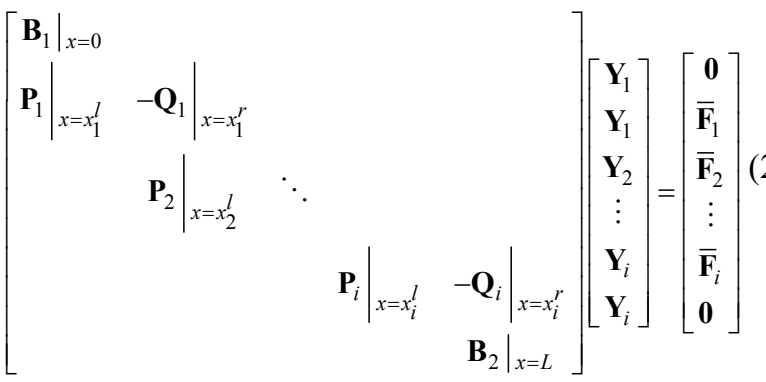

where $\overline{\mathbf{F}}_{n}=\left[\begin{array}{llll}0 & 0 & F_{n} & 0\end{array}\right]^{T}$ on the $n$th bearing location of $x_{n}$.

\section{Validation of the model and hull deformation}

An example about a kind of "8530TEU" container ship [19] is carried on investigating vibration characteristics of the propulsion model taking hull deformations into consideration.

Tab. 1 and Tab. 2 show some parameters of the "8530TEU" container ship hull and the propulsion shaft. The propulsion shaft is redistricted into several parts from the propeller end to the shaft right end in order to calculate conveniently.

Table 1 The "8530TEU" container ship parameters [19]

\begin{tabular}{|c|c|c|c|}
\hline Dimension & & Dimension & $13,00 \mathrm{~m}$ \\
\hline L. O. A & $335,00 \mathrm{~m}$ & Design Draught & $14,65 \mathrm{~m}$ \\
\hline L. B. P & $320,00 \mathrm{~m}$ & Scantling Draught & 101000 DWT \\
\hline Breadth mld & $42,80 \mathrm{~m}$ & Deadweight & $8530 \mathrm{TEU}$ \\
\hline Depth mld & $24,80 \mathrm{~m}$ & Container Loading & \\
\hline
\end{tabular}

Table 2 The "8 530 TEU" container ship propulsion parameters

\begin{tabular}{|l|c|c|c|}
\hline \multicolumn{1}{|c|}{ Dimension } & & Dimension \\
\hline Total length $L$ & $46,886 \mathrm{~m}$ & $4^{\text {th }}$ journal bearing stiffness $k_{4}$ & $1,0 \times 10^{9} \mathrm{~N} / \mathrm{m}$ \\
\hline Diameter of shaft $D$ & $0,795 \mathrm{~m}$ & $5^{\text {th }}$ journal bearing stiffness $k_{5}$ & $1,0 \times 10^{9} \mathrm{~N} / \mathrm{m}$ \\
\hline Number of bearings & 5 & $1^{\text {st }}$ shaft beam length $L_{1}$ \\
\hline Mass of propeller $m_{p}$ & $92580 \mathrm{~kg}$ & $2^{\text {nd }}$ shaft beam length $L_{2}$ \\
\hline Rotation inertia $j_{p}$ & $896174,4 \mathrm{~kg} \cdot \mathrm{m}^{2}$ & $3^{\text {rd }}$ shaft beam length $L_{3}$ \\
\hline $1^{\text {st }}$ stern bearing stiffness $k_{1}$ & $0,75 \times 10^{9} \mathrm{~N} / \mathrm{m}$ & $4^{\text {th }}$ shaft beam length $L_{4}$ & $7,738 \mathrm{~m}$ \\
\hline $2^{\text {nd }}$ stern bearing stiffness $k_{2}$ & $0,80 \times 10^{9} \mathrm{~N} / \mathrm{m}$ & $5^{\text {th }}$ shaft beam length $L_{5}$ & $7,750 \mathrm{~m}$ \\
\hline $3^{\text {rd }}$ journal bearing stiffness $k_{3}$ & $1,00 \times 10^{9} \mathrm{~N} / \mathrm{m}$ & $6^{\text {th }}$ shaft beam length $L_{6}$ & $11,288 \mathrm{~m}$ \\
\hline
\end{tabular}

\subsection{Validation}

In order to validate the accuracy of the mathematical model established in section 2, the natural frequency parameters of the propulsion system obtained in presented mathematical model will be compared with the results from ANSYS program which are shown in Tab. 3. Based on the propulsion parameters in Tab. 2, the results gained by presented mathematical model agree well with those from ANSYS program which confirms the accuracy of established mathematical model.

For further validation, an excited force with $100 \mathrm{~N}$ are adopted to applied on the $1^{\text {st }}$ stern bearing to generated vibration responses of the propulsion. Comparison of the responses of the propulsion at the propeller end between ANSYS program and presented model is shown as Fig. 2.

Table 3 Comparison of natural frequencies of the propulsion system between ANSYS program and presented model

\begin{tabular}{|c|c|c|c|}
\hline Mode No. & ANSYS / Hz & Present / Hz & $\begin{array}{c}\text { Difference } \\
\text { value }\end{array}$ \\
\hline 1 & 4,84 & 5,07 & $-0,23$ \\
\hline 2 & 6,19 & 5,75 & 0,44 \\
\hline 3 & 14,89 & 14,77 & 0,12 \\
\hline 4 & 18,02 & 17,79 & 0,23 \\
\hline 5 & 25,13 & 25,22 & 0,09 \\
\hline 6 & 28,37 & 27,86 & 0,51 \\
\hline 7 & 34,36 & 33,91 & 0,45 \\
\hline 8 & 39,03 & 38,23 & 0,80 \\
\hline
\end{tabular}




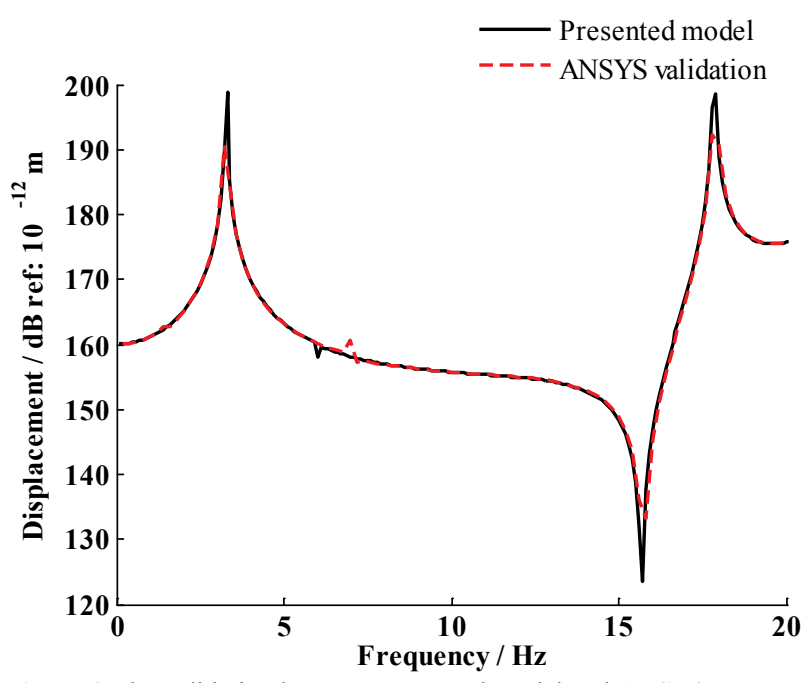

Figure 2 The validation between presented model and ANSYS program

From Fig. 2, it can be seen that further case studies for the propulsion model are convinced by the good agreement of the dynamic response results between the presented propulsion mathematical model and ANSYS program.

\subsection{Hull deformations}

During operation, the ship is assumed to experience severe hydrodynamic loadings due to the sea waves. A standard sea state classification is produced by WMO
(World Meteorological Organization) in 1970 and shown in Tab. 4. In the context of Tab. 4, the significant wave height is the mean value of the highest third of a large number of peak-through wave heights [20].

In order to predict the resultant motions of the vessel and get the hull deformations caused by hydrodynamic loadings in a realistic manner, a complex ship FEM model is developed as Fig. 3. The shape of a typical wave is described as sinusoidal where the hull is deformed in a same profile.

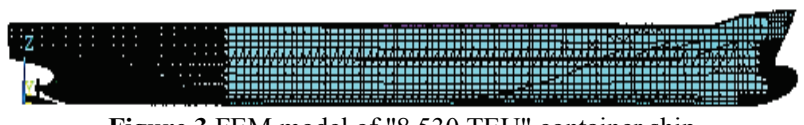

Figure 3 FEM model of "8 530 TEU" container ship

In this paper, we choose the very rough sea wave condition (Sea state code 6) with wave height of 5 meters as the excited wave loading to obtain the hull deformations. Based on the fluid-structure theory and the finite element method, the hull deformations on the location of bearings are generated, as shown in Tab.5, during the ship operating in some typical sea conditions. Three typical cases with different wave directions are given in Tab. 5 as well as the amplitude of the deformations. Furthermore, the forces referred to as in Eq. (7) can be easily obtained by Hooke's law.

Table 4 The World Meteorological Organization's codes for sea state [20]

\begin{tabular}{|c|c|c|c|c|}
\hline $\begin{array}{c}\text { Sea state } \\
\text { code }\end{array}$ & Band of Sea Wave & $\begin{array}{c}\text { Significant Wave Height } \\
\mathrm{m}\end{array}$ & $\begin{array}{c}\text { Sea state } \\
\text { code }\end{array}$ & $\begin{array}{c}\text { Significant Wave } \\
\text { Height } / \mathrm{m}\end{array}$ \\
\hline 1 & Calm-Glassy & $H_{\mathrm{s}}<0,1$ & 6 & Very Rough \\
\hline 2 & Calm-Rippled & $0,1 \leq H_{\mathrm{s}}<0,5$ & 7 & High \\
\hline 3 & Smooth-Wavelet & $0,5 \leq H_{\mathrm{s}}<1,25$ & 8 & $6,0 \leq H_{\mathrm{s}}<6,0$ \\
\hline 4 & Moderate & $1,25 \leq H_{\mathrm{s}}<2,5$ & 9 & Very High \\
\hline 5 & Rough & $2,5 \leq H_{\mathrm{s}}<4,0$ & & $H_{\mathrm{s}}$ - significant wave height \\
\hline
\end{tabular}

Table 5 Hull deformations in typical sea wave conditions

\begin{tabular}{|c|c|c|c|c|c|c|c|c|}
\hline \multirow[b]{2}{*}{ Case } & \multirow[b]{2}{*}{$\begin{array}{l}\text { Sea state } \\
\text { code }\end{array}$} & \multirow{2}{*}{$\begin{array}{c}\text { Wave } \\
\text { direction } \\
/^{\circ}\end{array}$} & \multirow{2}{*}{$\begin{array}{c}\text { Wave } \\
\text { frequency } \\
/ \mathrm{rad} / \mathrm{s}\end{array}$} & \multicolumn{5}{|c|}{ Hull defromations on each bearing / $\mathrm{mm}$} \\
\hline & & & & $1^{\text {st }}$ stern bearing & $\begin{array}{l}2^{\text {nd }} \text { stern } \\
\text { bearing }\end{array}$ & $\begin{array}{c}3^{\text {rd }} \text { journal } \\
\text { bearing }\end{array}$ & $\begin{array}{c}4^{\text {th }} \text { journal } \\
\text { bearing }\end{array}$ & $\begin{array}{c}5^{\text {th }} \text { journal } \\
\text { bearing }\end{array}$ \\
\hline Case 1 & 6 & 0 & 1 & 1,095 & 5,910 & 8,553 & 11,895 & 9,831 \\
\hline Case 2 & 6 & 90 & 1 & 0,551 & 1,352 & 3,376 & 7,016 & 7,501 \\
\hline Case 3 & 6 & 180 & 1 & 1,061 & 5,896 & 8,131 & 10,802 & 8,867 \\
\hline
\end{tabular}

\section{Vibration analysis of the model \\ 4.1 Case study}

Based on the data derived in section 3 , three typical cases in which the ship operates are investigated. With a concentrated mass in the end of the propulsion, the stern shaft is always operating in a more tough condition. As a result, the propeller ends of shaft are chosen as the monitoring point to study the effect of the hull deformations on the propulsion system. The analysis result in Fig. 4 shows that in the cases 1 and 3, the displacements of the shaft on the propeller end is larger than that in the case 2 . It is because when the sea wave is in 0 degree and 180 degree directions, the vertical component of hydrodynamic force on the ship hull along the $o-y$ coordinate axis is much larger than that in the 90 degree direction. As a result, hull deformations on the support bearings in case 1 and case 3 are larger than those in case 2 .

It is known that in the ocean storms the ship is always keeping steaming beat to sea which is similar to case 3 conditions. The frequency of the wave attack to the hull is high in the ocean storms, which leads to a high frequency of hull deformations. From Fig. 4 it can be seen that in higher excited hull deformations frequencies, the displacements of the shaft on the propeller end in case 3 are larger than those in other two cases. In this case, decreasing the speed of the ship could be adopted to keep the safety of the ship effectively. 


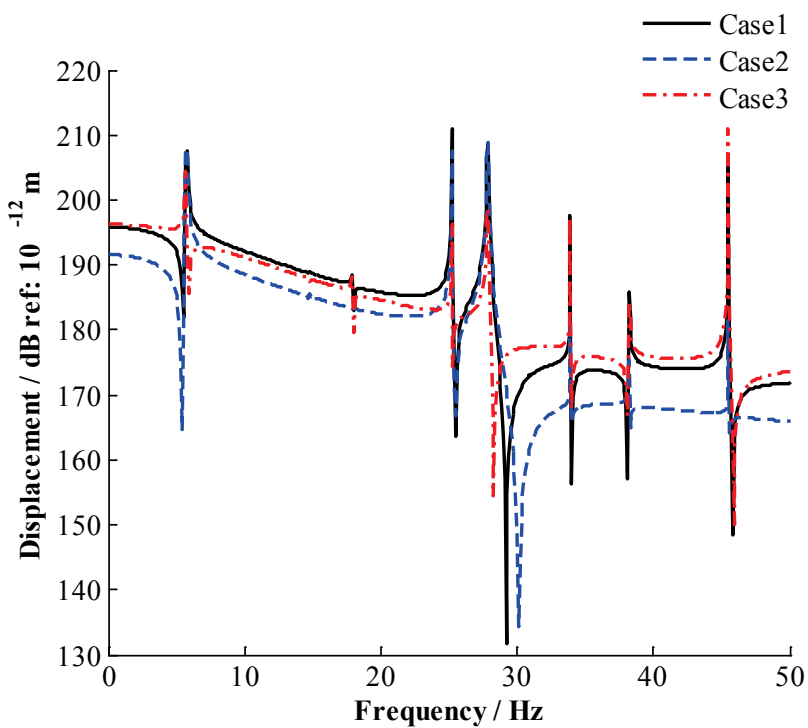

Figure 4 Dynamic response of the shaft on the propeller end among three cases

\subsection{Effects of general stiffness of stern bearings}

Compared with other bearings, stiffness of the stern bearing is lower. It is because the lubrication methods of stern bearing are quite different from other bearings and different wear resisting materials with different stiffness are added into the stern bearings.

Factor $\varepsilon$ is introduced to illustrate the relationship between the stiffness of stern bearing and the bending stiffness of the propulsion shaft. Based on the typical case 3 which is a more critical condition in comparison with other two conditions, the dynamic response of the shaft with different stiffness of the aft-stern bearing and bestern bearing is studied, respectively, shown in Fig. 5 and Fig. 6.

From Fig. 5, it can be seen that with the increase of the stiffness of the aft-stern bearing till $\varepsilon_{1}$ around 2, the displacements of the shaft have a decreasing trend in a low range of excited hull deformation frequency. However, the excited hull deformation frequencies at which the displacements of the shaft reach the peck are the same due to the resonant frequency of shaft. The maximum displacements of the shaft with different stiffness of stern bearing are various especially in the range of $30 \div 40 \mathrm{~Hz}$. When $\varepsilon_{1}$ exceeds 2 , the displacements of the shaft tend to be stable. It is because of the fact that when the stiffness of stern bearings is quite larger than that of the bending stiffness of the shaft, the bearing can be regarded as rigid. As the bearing will not be deformed by the hull deformations, the shaft will receive the excited forces from the hull directly. When the stiffness of the bearing is quite large, the shaft will be easily be damaged by rigid bearings. Furthermore, if the stiffness of the bearings is low, violent vibration of the propulsion shaft will occur. For this kind of ship, it can be found that the stiffness ratio between the stern bearing and the shaft around 2 will best keep the propulsion in relatively low amplitude.

In Fig. 6, it is shown that with the increase of the stiffness of the be-stern bearing, the vibration of shaft is relatively smooth during the excited hull deformation frequency from 0 to $30 \mathrm{~Hz}$. Similarly, in the range of
$30 \div 40 \mathrm{~Hz}$, the maximum displacements of the shaft are also various, which means the shaft will very easily suffer damage from the hull excitations. Comparing Fig.5 and Fig. 6, different locations of the stern bearings have different effect on the shaft. The study in this subsection provides a method for the designer and constructor to choose the stiffness of stern bearings to avoid damage. Moreover, based on this method, other bearings can also be analysed to find the suitable stiffness for them.

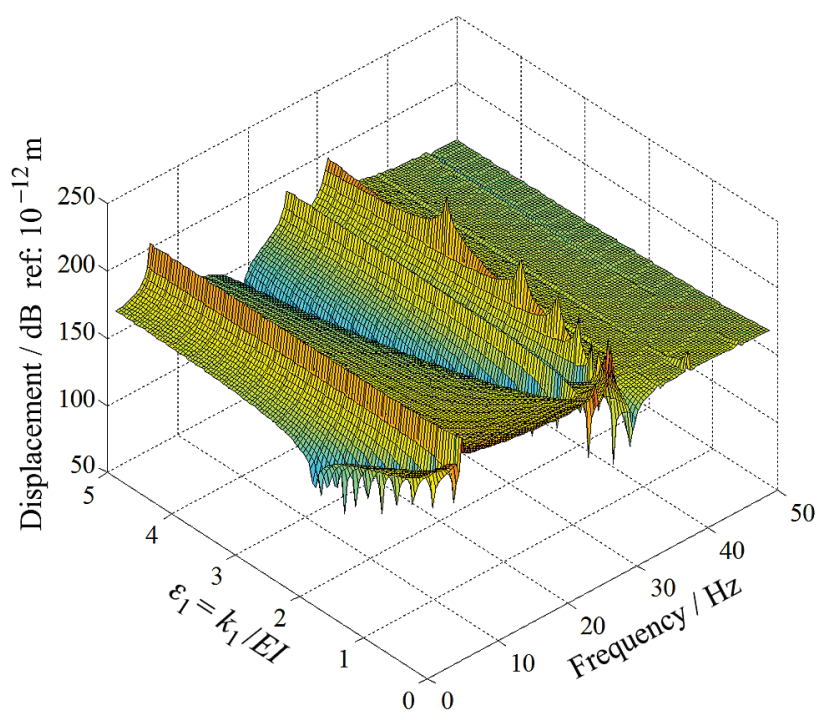

Figure 5 Dynamic response of the shaft on the propeller end with different aft-stern bearing stiffness

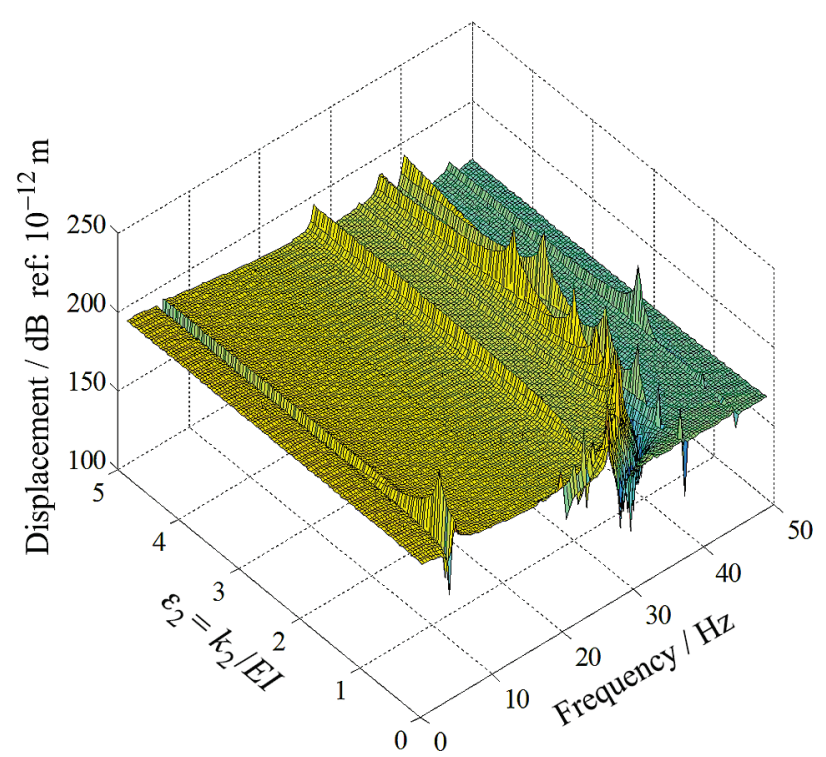

Figure 6 Dynamic response of the shaft on the propeller end with different be-stern bearing stiffness

\section{Conclusion}

With the rapid increase of the size for the vessels, the coupled effect between ship hull and propulsion system has been increasing to threaten the reliability and safety for the power system. In this paper, a novel simplified hull-propulsion system mathematical model is presented to investigate the dynamic interactions between the ship propulsion and hull deformations. The accuracy of the mathematical model is verified by the FEA method. Based on the presented model, it provides a fast way to 
calculate the natural frequency and dynamic response by using the dimension and property parameters.

Meanwhile according to a kind of large ship operating in different sea wave conditions, the dynamic responses of the propulsion excited by hull deformations are discussed. The traditional method to choose the stiffness of bearing to decrease the effect of hull deformation on the propulsion shaft is always based on empirical calculation. The mathematical model also provides a convenient method for ship designer and constructor to choose suitable stiffness of stern bearing to reduce the damage of the propulsion system. Based on this analysis and findings, salutary references and method are afford to prevent accidents of propulsion which are caused by hull deformations.

Further, the interaction between the propeller and water will be investigated to perfect the mathematical model and more cases will be studied to validate the model.

\section{Acknowledgements}

This research was funded by the Key Program of National Natural Sciences Foundation of China (NSFC) (No. 51139005) and the Fundamental Research Funds for the Central Universities (WUT: 2014-JL-006).

\section{References}

[1] Li, Z. X.; Yan, X. P.; Qin, L.; Yuan, C. Q.; Peng Z. X. Model reference robust control for marine propulsion systems with model deformation. // Journal of Marine Science and Technology. 21, 4(2013), pp. 400-409. DOI: 10.6119/JMST-012-0518-5

[2] The Swedish Club Highlights, 2005. URL: http://www.swedishclub.com/upload/highlights/main_engin e damage update 2005 web.pdf. (09. 2005).

[3] The Swedish Club Highlights, 2012. URL: http://www.swedishclub.com/upload/highlights/main_engin e damage_2012.pdf. (09. 2012).

[4] Yan, X. P.; Li, Z. X.; Liu, Z. L.; Yang, P.; Zhu, H. H.; Yang, Z. M.. Study on coupling dynamical theory for interaction of propulsion system and hull of large ships: a review. // Journal of Ship Mechanics. 17, 4(2013), pp. 439449. DOI: 10.3969/j.issn.1007-7294.2013.04.014

[5] Zhang, G. B.; Zhao Y.; Li, T.; Zhu, X. Propeller excitation of longitudinal vibration characteristics of marine propulsion shafting system. // Shock and Vibration. 2014(2014), pp.1-19. DOI: 10.1155/2014/413592

[6] Li, Z. X.; Yan, X. P.; Qin, L.; ChenK.; Xing, J. T. Robust global sliding model control for water-hull-propulsion unit interaction systems Part 1: system boundary identification. // Tehnicki vjesnik-Technical Gazette. 22, 2(2015), pp. 465473. DOI: $10.17559 /$ TV-20141208054126

[7] Li, Z. X.; Yan, X. P.; Qin, L.; Chen K.; Xing, J. T. Robust global sliding model control for water-hull-propulsion unit interaction systems Part 2: model validation. // Tehnicki vjesnik-Technical Gazette. 22, 1(2015), pp. 209-215. DOI: 10.17559/TV-20141208054604

[8] Senjanovic, I.; Catipovic, I.; Tomasevic, S. Coupled flexural and torsional vibrations of ship-like girders. // Thin Walled Structure. 45, 12(2007), pp. 1002-1021. DOI: 10.1016/j.tws.2007.07.013

[9] Firth, J.; Black, J. Vibration interaction in a multiple flywheel system. // Journal of Sound and Vibration. 331, 7(2012), pp. 1701-1714. DOI: 10.1016/j.jsv.2011.11.028
[10] Wang, H.; Wei H.; Guan, D. Numerical simulation on ship shafting mechanics conditionof intermediate bearing. // Journal of Ship Mechanics. 10, 1(2006), pp. 98-105. DOl: 10.3969/j.issn.1007-7294.2006.01.013

[11] Murawski, L. Shaft line alignment analysis taking ship construction flexibility and deformations into consideration. // Marine Structures. 18, 3(2005), pp. 62-84. DOI: 10.1016/j.marstruc.2005.05.002

[12] Xiong, Y.; Xing J. T.; Price, W. Interactive power flow characteristics of an integrated equipment-nonlinear isolator-travelling flexible ship excited by sea waves. // Journal of Sound and Vibration. 287, 2(2005), pp. 245-276. DOI: 10.1016/j.jsv.2004.11.009

[13] Bishop, R. E. D.; Price, W. G.; Wu, Y. S. A general linear hydroelasticity theory of floating structures moving in aSeaway. // Philosophical Transactions of the Royal Society of London Series. 316, 1538(1986), pp. 375-426. DOI: http://dx.doi.org/10.1098/rsta.1986.0016

[14] Liu, C.; Che, D.; Shen, X. Experimental and numerical study on vibration of the full-revolving propulsion ship stern. // China Ocean Engineering. 29, 1(2015), pp.33-48. DOI: 10.1007/s13344-015-0003-5

[15] Yang, Y.; Che, C.; Tang, W. Shafting coupled vibration research based on wave approach. // Journal of Shanghai Jiaotong University. 19, 3(2014), pp. 325-336. DOl: 10.1007/s12204-014-1506-6

[16] Tian, Z.; Yan, X. P.; Li, Z. X. Dynamic interaction analysis of a $2 \mathrm{D}$ propulsion shaft-ship hull system subjected by sea wave. // ASME $201433^{\text {rd }}$ International Conference on Ocean, Offshore and Arctic Engineering / San Francisco USA, 2014. DOI: 10.1115/OMAE2014-23795

[17] Balakumar, B.; Edward, B.; Vibrations. $2^{\text {nd }}$ ed. Toronto: Thomson West, 2009.

[18] Clough, R.; Penzien, J. Dynamics of structures. Berkeley: Computers \& Structures Inc, 2005.

[19] Hudong, Co. Ltd. 8530 TEU container ship. // Ship Engineering. 4, 2(2008), pp. 91.

[20] Carlton, J. Marine propellers and propulsion. $3^{\text {rd }}$ ed. London: Butterworth-Heinemann, 2012.

\section{Authors' addresses}

\section{Zhe Tian, PhD}

1) School of Energy \& Power Engineering, Wuhan University of Technology, Wuhan 430063, China

2) Key Laboratory of Marine Power Engineering \& Technology (Ministry of Communications), Wuhan 430063, China

3) National Engineering Research Center for Water Transport Safety, Wuhan 430063, China

4) Fluid Structure Interaction Research Group, Faculty of Engineering and the Environment, University of Southampton, Southampton, SO17 1BJ, UK

E-mail: tianzhe@whut.edu.cn

Xinping Yan, PhD, Professor (corresponding author)

1) School of Energy \& Power Engineering, Wuhan University of Technology, Wuhan 430063, China

2) Key Laboratory of Marine Power Engineering \& Technology (Ministry of Communications), Wuhan 430063, China

3) National Engineering Research Center for Water Transport

Safety, Wuhan 430063, China

E-mail: xpyan@whut.edu.cn

Cong Zhang, PhD, Lecturer

1) School of Energy \& Power Engineering, Wuhan University of Technology, Wuhan 430063, China

2) Key Laboratory of Marine Power Engineering \& Technology

(Ministry of Communications), Wuhan 430063, China

3) National Engineering Research Center for Water Transport

Safety, Wuhan 430063, China

E-mail: zhangcong@whut.edu.cn 


\section{Yeping Xiong, PhD, Associate Professor}

Fluid Structure Interaction Research Group, Faculty of Engineering

and the Environment, University of Southampton, Southampton,

SO17 1BJ, UK

E-mail: Y.Xiong@soton.ac.uk

\section{Ping Yang, PhD, Professor}

School of Transportation, Wuhan University of Technology,

Wuhan 430063, China

E-mail: pyang@whut.edu.cn 